\title{
FAILING IN BASIC SCHOOL: DISCOURSES OF EXPLANATION
}

\author{
Mare Müürsepp, Anne Uusen \\ Tallinn University, Tallinn, Estonia \\ E-mail: mare.muursepp@tlu.ee, anne.uusen@tlu.ee
}

\begin{abstract}
Discourse study was aimed to analyse the methodolody of educational research concerning problems of failing in basic school. There the gender discourse appeared as a substantial issue, while remarkable differences between boys and girls are revealed by official statistics and educational studies.

The sustainability of a society with such a gender imbalance in education is at risk, since the educational choices will influence choices in the labor market and in lifestyle in broader terms. It is therefore important to look for explanations for gender differences in education (coping strategies, achievement, etc.). In line with the theories of multiple masculinities can be argued that looking at the so-called failing boys as a homogenous group will not take us very far in understanding the underlying reasons for the causes of failing. If the coping at school is related to the gender, then the solution of the problem has to be derived from the gender differences too, but this kind of thinking would connote to the gender stereotypes.

Thus, a historical overview of educational research carried out in Estonia in the last century is provided, focusing on the discourse of gender in the educational science. There are different periods pointed out in relation to the focus in studies of academic success: there have been years, when the boys' results in academic skills were higher than girls' results; problems of health and social relations have been treated in different way during different periods. Content analysis of the studies concerning gender issues will be the basis for the discussion, and special attention will be given to the research of pupils'lifestyle.
\end{abstract}

Key words: coping, essentialist vs. sociocultural approach, gender, lifestyle, multiple masculinity.

\section{Introduction: Gender and Lifestyle in Educational Research}

According to the data of longitudinal sociological study "Work, home and leisure time 1985-2008" there are evidences about men's lower life quality, like a remarkable amount of men in different age groups, who are less satisfied with their life and less engaged in cultural activities than women of the same age groups (Müürsepp, 2009). Named fact is in compliance with the results of studies of pupils' coping at school, where the boys like school less than girls and boys' academic achievement is lower than girls' results (Leino, Veisson, Ruus, Sarv, Ots \& Veisson, 2008). The experts of PISA 2009 claim even that girls are almost one year ahead than boys in reading performance for example (EU, 2012). Statistics about young people in categories 'not in education, employment and training' (NEET) and 'in jobs without training' (JWT) confirm that there are the boys predominantly (Spielhofer 2009). Might the cultural and educational backwardness be a gender issue?

Current study analyzed the articles published during the 20th century in Estonian educational scientific journals to look for the explanations of the school success: with what is success or failure connected besides gender? How the gender differences are disserted in theoretical context of modern gender research? 
$\begin{array}{r}\text { PROBLEMS } \\ \text { OF EDUCATION } \\ \text { IN THE 21 } 1^{\text {st }} \text { CENTURY } \\ \text { Volume 48, 2012 } \\ \hline 118\end{array}$

Theoretical Background

Concept of discourse is used in tradition by Michel Foucault interpreting discourse as a system of representations (Hall, 1997). Way of representation of the gender was a starting point for the analysis of the articles reflecting empirical research in basic school during the $20^{\text {th }}$ century.

Coping at school has been defined as an individual's adaption to the environment: meaning as individual's effort to maintain control over events in the process of study (School, 2008). Aspects of coping include academic success, participation in learning activities, psychosocial well-being at school, pupils' interests and school climate (School, 2008). The youth groups NEET and JWT could be treated as opposite phenomena to school coping. The studies explain that such young people do not constitute a homogenous group (Spielhofer, 2009).

Proceeding from theoretical origin (Hall, 1997; Laherand, 2008) the discourse might include different and even opposite meanings systems, as well as gender discourse would comprise different treatments of gender.

Studies carried out in last decades have shown that gender in education is a much more complex issue than any statistics can reveal. There is the need to go beyond official numbers by employing qualitative research methods to investigate boys' coping strategies. In Scandinavian countries and the UK there is a strong tradition of ethnographic studies (Lahelma, 2005) that allows the researcher to study the coping strategies of individual students, both boys and girls. The questions to ask include the following: why do some boys fail more probably than others? What are the underlying causes for the failure? In understanding the multiple nature of masculinity, it has become clearer that some aspects of failure are explained by additional factors such as ethnic background, social status, life style, etc. (Kimmel, 2010). Gender intersects with other social factors and it is only question about taking into account the variety of these factors that any meaningful explanations for the success or failure of boys in education can be provided.

Boys perform their masculinity in numerous ways. These ways are hierarchically structured and expressed in discourses of power. Hegemonic masculinity stands on top of the power hierarchy and refers to "a position, which is achieved as a result of collective cultural and institutional practices, and asserts its authority through these practices particularly through the media and the state" (Skelton, 2001, referring to Kenway, 1997). Hegemonic masculinity is constructed vis-à-vis women and other, subordinated forms of masculinity and reinforces the dominance of white, middle class, heterosexual men in the society (Kimmel, 2011).

The analysis of the approaches to boys in the past educational studies is influenced by the theories of multiple masculinities (Connell, 2005; Haywood \& Mac an Ghaill, 2003). In discussions about gender two main general approaches are applied: essentialist and socioconstructive. According to the essentialist understanding of gender, men and women are different by birth, there is the belief that gender differences would be a natural thing. Oppositely, the socio-constructivists claim that gender differences are the outcome of different socialization processes (DeLamater \& Hyde, 1998; Kirss, 2011; Kuurme, 2011).

The notion of lifestyle is proposed as a possible way to treat the coping strategies, while there are different characteristics of the personality integrated in the lifestyle (Hartman, 1999; Liimets, 2009). In educational sciences in Estonia the concept of lifestyle become central already in the 1970s. Academician Heino Liimets, in explaining the development and behavior of human beings, applied the activity theory characteristic of both Russian psychology (e.g. Lev Vygotsky, Aleksei Leontjev) and reform pedagogy. In Liimets' view, the underlying problem was the lack of adequate integration between school-work and other activities forming a person's system of life activities. This low integration is often the reason, why school and studying become unpleasant. Such an educational sociological approach to learning has been considered quite original in an international comparison (Liimets, A., 1998). Liimets defined 
lifestyle as a psychic condition that ensures a relative adaptation of a personality to all his/ her life conditions, finding support in the resources gathered in the earlier development such as knowledge, skills and experiences, already existing capabilities, needs and interest, social attitudes, individual peculiarities of development, the developmental level of self-consciousness and the ability of self-regulation. The existing personality-related resources enable, with larger or smaller efficiency, to get involved in activities and communication, in self-realization. On the one hand, the involvement depends on the opportunities and abilities of a person, on the other hand also on the mutual relationships of a person and a group, on the availability of help and support, on how teachers and other educators understand the development situation of each individual student (Liimets, H., 1998).

\section{Problem of Research}

Educational science has to support the practicians in their everyday work. By Foucault the discourse constructs the topic, defining and producing the objects of knowledge (Hall, 1997). The knowledge acquires authority of "the truth". The results of educational statistics amplified by the media had formed the school reality. The aim of the current research was to map the phenomena of coping at school according to the studies carried out during the $20^{\text {th }}$ century in Estonian school, and to analyze these in the context of contemporary gender theory. To avoid the embedding of gender stereotypes the other directions of thought would be important to point out.

\section{Research Focus}

The research focused on empirical studies about coping and failing in basic school, analyzing the explanations of failing. The factors related to failing were pointed out. How the methodology of studies reflects discourse of gender? In line with the theories of multiple masculinities (Connell, 2005) is argued that looking at the so-called failing boys as a homogenous group (as expressed in official statistics and also some educational studies) will not take us very far in understanding the underlying reasons for the causes of failing. The second argument of the study is that the problems of boys in education (as well as gender in more general terms) should be viewed in a historical context, since the context has played a major role in the general gender discourse.

\section{Methodology of Research}

\section{General Background of Research}

Although the study concentrates on educational history of a concrete country, the treatment is international by the substance, as the educational reality in Estonia has formed under the influence of various cultures. Imported knowledge and ideas from social sciences of German, Russian, French, Anglo-American and Scandinavian tradition have been integrated into the tradition of national education. In the second half of the $20^{\text {th }}$ century our education was dominated by the Soviet educational ideology. At the same time, the Soviet educational system and educational science have been viewed by influential Western experts as including ideas not very relevant in the Western educational system (Bronfenbrenner, 1973). Specially the ideas of supporting the development of a child as a whole has been pointed out (Alexander 2001, 2004).

The principle of gender equality was recognized in the Soviet society: there were famous women tractor-drivers, crane-drivers and cosmonauts. However, ignoring any gender 
PROBLEMS

OF EDUCATION

IN THE $21^{\text {st }}$ CENTURY

Volume 48,2012

differences in education led in the 1970 s to the need to introduce family life education into the curriculum that would guide students to fulfill the role of the man and the woman.

Independence in the late 1980s brought along the revival of the ideals of the pre-war period of independence. While so far gender equality had been declared, in the education of the newly re-born republic gender stereotypes in a national-romantic mood became to be stressed.

Methodology of the current study followed the binary opposition of essentialist and socio-constructivist discourses inside of gender discourse to analyze school failing factors in Estonian educational research carried out during the $20^{\text {th }}$ century.

\section{Sample of Research}

The review uses the database including 276 articles about the problems of basic school, compiled in 2005 for the doctoral study (Müürsepp, 2005). The articles reflecting educational research published in the leading scientific educational journals 1919-1940 (Kasvatus/ Education), 1941-1991 (Nõukogude Kool/Soviet School) and 1991-2012 (Haridus/Education) were analyzed from the viewpoints of gender issues and coping. There are 39 articles selected to maintain the focus of the present treatment. The principles for selection of the articles were: 1) the article presents a research report, concentrating on an actual empirical study concerning social and academic coping of basic school pupils; 2) the method and results of the study are given in the article.

\section{Instrument and Procedures}

Document analysis as a qualitative research method has been used to analyze the articles on issues of coping at school. Since the aim of the study was to map and categorize the studies by the theoretical framework of gender discourse, the analysis stems from theoretical concepts and directed content analysis has been used (Hsieh \& Shannon 2005, Mayring 2000). Studies were classified by the theoretical basis reflected in report and conclusions as 'explaining the school success by the gender issues or justifying by other characteristics'; the studies dealing with the gender aspect have been categorized into essentialist and socio-constructivist. This enables to conclude which studies explain the failure of boys in line with modern theoretical concepts in gender studies (multiple masculinity, socio-constructive approach). The articles were coded based on the method of research (qualitative-quantitative) and the line of argumentation (essentialist, socio-constructive) and a table of analysis generalizing the studies were made.

\section{Data Analysis}

According to the aim of the study the research reports introduced in the articles were analyzed by the aspects concerning on the coping at school. The aspects concerning the coping at school were specified both by the theoretical reasoning reflected in the report and by the results and the conclusions of the study reflected in the articles.

In searching the aspects of the academic and social coping in educational research, the studies can be divided into several categories: qualitative and quantitative, studies based on essentialist and socio-constructive explanations. Based on the interpretation of research results articles could also be coded according to whether the results were presented by opposing boys and girls, by looking at them only as groups distinguished by gender or by finding subgroups and forming typologies where gender was not the primary category. 


\section{Results of the Research}

Factors of Coping

There are many different matters mentioned by the reports in different periods. School success have been analyzed in connection with pupils' geographic location, their parents' profession and educational level, pupils' somatic condition, health, age, gender differences in physiological development, gender stereotypes and also generally determined economiccultural factors, pedagogical-medical problems and lifestyle issues mentioned. The variety of emphasis depends on the variety of the researchers - there are the studies conducted by medical workers, sociologists and other working together with educational researchers. The most important groups of factors related to coping in school are presented on the figure 1, there is the relative frequency of the factors given.

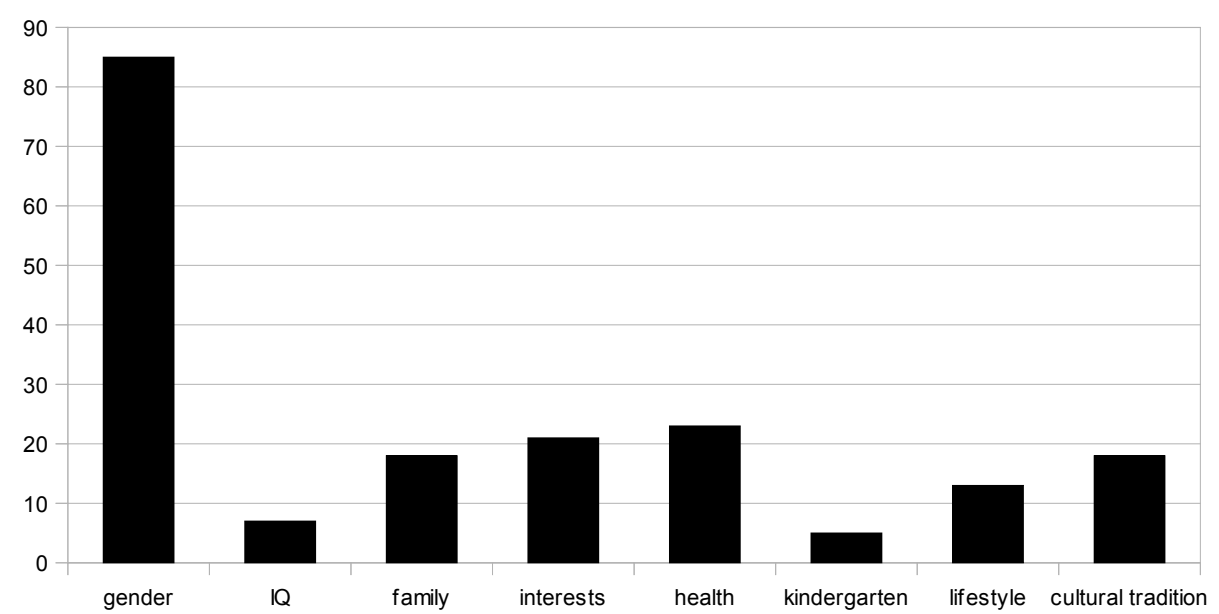

Figure 1: Factors related to coping in school according to the empirical studies.

\section{Historical context}

Also the emphasis depends on the leading ideology of certain historical period. In the 1920-1930s the focus in the educational sciences of the new national state was on the implementation of the approaches developed in Western countries to develop the national school. Measurement of intelligence through tests was considered relevant as well as studying the interests of young people. According to the studies of the 1930s, boys showed better intellectual capabilities and were more successful than girls in some types of schools (private schools). In the Soviet period Estonian educational researchers became the members of Soviet Union-wide research programs. Since the development of the scientific potential became the central task due to the cold war, educational research focused on the effectiveness of teaching. There are new aspects like issues of health (since 1963) and lifestyle (since 1969) remarkable in the research. 
PROBLEMS

OF EDUCATION

IN THE $21^{\text {st }}$ CENTURY

Volume 48,2012

122

\section{Gender Discourse}

Proceeding the opposition inside of gender discourse the studies were analyzed from the point of view expressed in the methodological arguments and interpretation of the results. More than half of the articles were written in the essentialist paradigm claiming that boys and girls are simply different, without explaining why students' academic results should be compared in terms of gender (Figure 2).

11 articles out of 39, including both those using qualitative research methodology and quantitative methodology, attempted to explain academic achievement and social coping by using the broader socio-constructivist approach, looking for different factors which could influence children's behaviors and evaluations, given to these behaviors. Based on research results these studies usually referred to student groups or types in which the gender was only a background factor.

There are 8 articles, where the gender is not a factor of analyze of school success. There are different types of studies presented, like sociological observation of the whole school class during a year, and there are typologies of children by teachers evaluation.

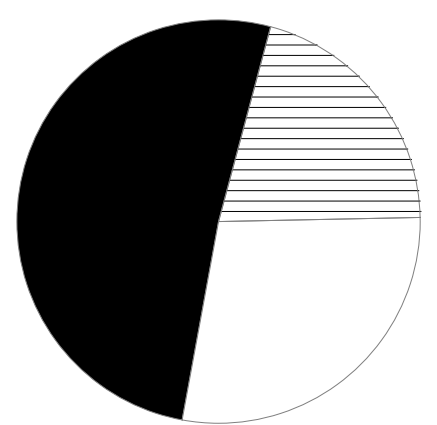

Figure 2: Gender interpretation in the educational studies.

\section{Lifestyle Discourse}

In several studies student types are distinguished and their choices of lifestyle serve as the basis for these distinctions. This line of research is closely related to today's gender discussions. Central among these studies is the project From Desk to Desk, which has been used as the example by Silvia Kera in her studies of basic school students (Kera, 1977, 1983).

According to Liimets and Kera the student-like way of life exhibits several characteristics/ indicators: studying/learning as the core activity, the relationship between studying and free time, age, social awareness - the relationship with other people (individualistic or collectivist the dimension of activity-passivity in action, the share of cultural values and their acquisition (Kera, 1977; Liimets, 2009). Educational scientists claimed that it is important to achieve that the way of life in school would be acceptable to students. To achieve that the work with students be differentiated, one should take into account the specific features of the way of life and the needs of individual students for self-realization/actualization, recognition and independence. In using the concept of lifestyle, Silvia Kera refers to the textbooks of psychology by Kazimiers Obuchowski, Vadim Olshanski, Tamotsu Shibutani. The educational work done in schools should meet the system of students' actual life. Based on the research of rather large samples of students by the researchers of Liimets' group and the work of Silvia Kera, the following typology emerges. Students can be described by or according to five different types of lifestyles 
in which also a certain amount of boys is included. Using the data of the study of Kera the behavior of boys related with learning can be described according to the following five types:

PROBLEMS

OF EDUCATION

IN THE $21^{\text {st }}$ CENTURY

Volume 48,2012

(I) dutiful/conscientious learner, has in-door interests; (II) generally passive, studies worse, relationship with the class is weak, has no specific interests; (III) active in school, studies little, but well, selects subjects to study, popular in class; (IV) versatile, likes the school the most, often active in nature, hard-working; (V) sports dominate, lower academic achievement, misses classes the most, less popular in class.

Consequently there would be different relations to academic demands presented by different lifestyle types; herewith there are different reasons to fail. When multiple masculinities are discussed, such a study of lifestyles would provide an opportunity to discuss in how many ways one could be a boy, how one or another lifestyle meets the expectations of the school and whether it is possible to find in schools strategies for coping that take into consideration different lifestyles.

\section{Discussion}

In searching for an explanation for the more frequent failure of boys, research done in different periods of times indicates that general rules/correlations are difficult to find (e.g. the relationship between pre-school preparation and the life as a student), that teachers experience a certain vague dislike of boys; that the reasons of dropping out of school are various and combined, that the problems related to coping with school become more and more individual (Tulva, 1986, 1992; Tulva \& Väljataga, 1999). There are the studies that have looked at preschool children and pinpointed the problem issues related with boys: falling ill more frequently (Tulva \& Tamm, 1971), lower quality nutrition of boys with learning problems (hinting at a low level of control of a child's daily schedule, Tulva, 1992), the negative communication tone of pre-school teachers in relation to children that have become marginalized (Vinter, 2006). It seems that little boys have been neglected more than little girls and the reason for it could be the gender stereotype of masculinity - the men should be more independent and become tough.

The study of school environment highlighted beliefs that are also important to know when analyzing lifestyle choices. Almost one third of teachers mentioned that in their school punishment is preferred to support, especially in case of behavioral problems. Most teachers consider the grade, i.e. the measured result of learning a subject, the main supporter of the students' development. Thus, the development of the personality of the students is seen as secondary (Sarv, 2008, 231). This conclusion is further supported by the fact that a large number of teachers do not consider conversations with students important and are neither aware nor interested in the students' problems. Therefore, it is rather expectable that a young person for whom communication is a very important part of their lifestyle (Must, 1986) will look for such a communication partner in their activities who is interested in them as a personality.

Concerning to the methodology of study of gender and lifestyle relations the classical note by Emile Durkheim should be remembered: the nature of child lies in her/his constant changing. A child is never ready (Durkheim, 2005). Therefore, in studying children longitudinal, repetitive studies should be preferred. Today, researchers in childhood studies consider it important to collect authentic material - the recording and analysis of children's own activities and speech. Studying gender in schools requires ethnographic methods of study as the childhood study generally (Prout \& James, 2005). Presenting statistical data as evidence for gender differences rather feeds the stereotypical view than explains the nature of problems.

Since the development of lifestyle is connected with the building of identity, this issue should be studied in close relationship with the child's own viewpoint (like 'story crafting' method, Karlsson, 2004, 2012). How does a young person see their life and their choices? How do the young people who have dropped out from the basic school, but later returned to studies evaluate their life and activities? 


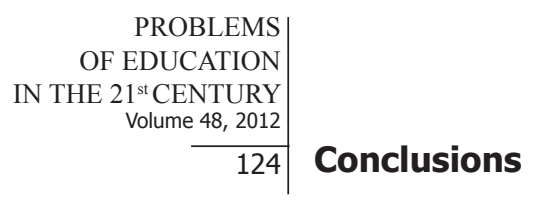

Historical material about coping in school was analyzed in frame of the contemporary gender discourse to reduce the risk of simplification in further research of school problems. Lively and interdisciplinary debate in gender studies enriches the discussion in educational research. In studying the gender aspect, the answers could be limited and also biased by questions that pose the opposition boys vs. girls, since one could on ground of such questions that boys and girls should be different in every matter. Presenting such an opposition by a researcher contradicts the concept of multiple masculinities and femininities.

Differences between and boys are often in research treated as a matter of course; the methodological reasoning does not reflect the ideas, why the boys and girls in certain field should be or might be different. As pointed out by Chalmers (1992), the results of the empirical study depend on the theoretical disposition of the researcher.

The current study highlighted the importance of studying gender aspects in education in connection with lifestyle studies of children. There are many different boys and many different lifestyles these boys lead. It is important to go beyond the statistical 'surface' and employ authentic methods of research to understand the underlying causes for certain lifestyle choices (story crafting, ethnographic studies, etc.). Studies of students' lifestyle can improve the understanding of children's choices when it comes to education, the reasons for their academic success and failure. The lifestyles studies in the basic school in the 1970s and 80s are definitely worth both: further development as well as doing it cross-culturally.

\section{Acknowledgements}

The authors wish to acknowledgements the help by Gertrud Kasemaa.

\section{References}

Alexander, R. (2001). Culture and Pedagogy: International Comparisons in Primary Education. Blackwell Publishers.

Alexander, R. (2004). Still no Pedagogy? Principle, pragmatism and compliance in primary education. Cambridge Journal of Education, 34 (1), 7-33.

Bronfenbrenner, U. (1973). Two Worlds of Childhood: U.S. and U.S.S.R. New York: Pocket Books.

Chalmers, A. F. (1992). What is this thing called Science? An assessment of the nature and status of science and its methods. Open University Press.

Connell, R. W. (2005). Masculinities. Berkeley; Los Angeles: University of California Press

DeLamater, J. D., \& Hyde, J. S. (1998) Essentialism vs Social Constructivism in the Study of Human Sexuality. The Journal of Sex Research, 35 (1), 10-18.

Durkheim, E. (2005). Childhood. In Childhood. Critical Concepts in Sociology. Edited by Chris Jenks. London and New York. Routledge. Vol 1, 25-29.

EU High Level Group of Experts on Literacy. Final Report, September 2012. http://ec.europa.eu/ education/literacy/what-eu/high-level-group/documents/literacy-report.pdf

Hall, S. (Ed) (1997). Representation: Cultural Representations and Signifying Practices. London: Sage.

Hartmann, P. H. (1999). Lebenstilforschung. Darstellung, Kritik und Weiterentwicklung. Opladen: Leske + Budrich.

Haywood, C., Mac and Ghaill, M. (2003). Men and masculinities: theory, research and social practice. Buckingham, Philadelphia: Open University Press.

Hsieh, H. F., Shannon, S. E. (2005). Three Approaches to Qualitative Content Analysis. Qualitative Health Research, November, 1277-1288. Retrieved 28/05/2012 from http://www.hu.liu. se/larc/utbildning-information/scientific-methodology/course-literature-and-links/1.253567/ Qualitative20Content20Analysis_1.pdf http://www.hu.liu.se/larc/utbildning-information/ scientific-methodology/course-literature-and-links/1.253567/Qualitative20Content20Analysis_ 1.pdf 
Karlsson, L. (2004). Storycrafting with Children. A Key to Listening and to Sharing.Retrieved 31/03/2012 from http://www.edu.helsinki.fi/lapsetkertovat/english/publishing/Karlsson_Storycrafting_with_ c_Semi.pdf

Karlsson, L. (2012). Lapsinäkökulmaisen tutkimuksen ja toiminnan poluilla. In Sukelluksia lapsinäkökulmaiseen tutkimukseen ja toimintaan. FERA, Suomen Kasvatustieteellinen Seura RY. Kasvatusalan tutkimuksia 57. Jyväskyla: Jyväskylän Yliopisto, 17-63.

Kera, S. (1977). Õpilaslikust eluviisist tulenevaid kasvatustaotlusi ja ülesandeid. [Educational aims and tasks proceeding the pupils' lifestyle] Nõukogude Kool 3, 199-203.

Kera, S. (1983). Õpilaste kasvatatuse analüüsi võimalusi. [Possibilities to analyse pupils' state of being educated] Nõukogude Kool 9, 16-19.

Kimmel, M. (2010). Boys and School: A Background Paper on the "Boy Crisis". Swedish Government Official Report. Stockholm.

Kirss, T. (2011). Sugu. [Gender] In Humanitaarteaduste metodoloogia. Uusi väljavaateid. Edited by Marek Tamm. Tallinn: Tallinna Ülikool, 263-279.

Kuurme, T. (2011). Haridus, kasvatus ja sugupool. [Education, cultural development and gender] In Sissejuhatus soouuringutesse. Tartu: Tartu Ülikool, 238-272.

Lahelma, E. (2005). School Grades And Other Resources: The "Failing Boys" Discourse Revisited. Nordic Journal of Women's Studies, 13 (2), 78-89.

Leino, M., Veisson, M., Ruus, V. R., Sarv, E. S., Ots, L., \& Veisson, A. (2008). Post-Socialist School - Sustainable for Boys or Girls? In School as Developmental Environment and Students' Coping: Aspects of Estonian school today. Compiled and edited by Loone Ots. Tallinn: Tallinn University, 195-213.

Liimets, A. (1998). Integratiivse teooria loomise taotlus. [Application to create an integrative theory] Eessõna Liimets, H. 1998. Kuidas õppeprotsess kasvatab. Tallinn: TPÜ kirjastus, 3-8.

Liimets, A. (2009). Muusika noorte elustiilis ja nüüdisaja koolikultuuris. [Music in young people's lifestyle and in contemporary school culture] In Muusikalise kontegelikkuse ühendused identiteedi ja diferentsiga. Tallinn: Tallinna Ülikool.

Liimets, H. (1998). Kuidas õppeprotsess kasvatab. [How does the learning process educate?] Tallinn: TPÜ kirjastus.

Mayring, P. (2000). Qualitative Content Analysis. Forum Qualitative Sozialforschung/Forum: Qualitative Social Research. [On-line Journal], 1 (2). Retrieved 25/05/2012 from http://qualitative-research. net/fqs/fqs-e/2-00inhalt-e.htm

Meiusi, M. (1932). Võrdlevaid andmeid laste vaimsest arenemisest. [Comparative data about children's mental development] Kasvatus, 5, 200-205.

Must, A. (1986). Kõik on kokku kasvuaeg. [There is time for growing up] Nõukogude Kool, 7, 17-19.

Müürsepp, M. (2005). Lapse tähendus eesti kultuuris 20. sajandil: kasvatusteadus ja lastekirjandus. [Meaning of the child in the Estonian culture in the $20^{\text {th }}$ century: educational sciences and children's literature] Tallinn: TPÜ.

Müürsepp, M. (2009) Vaba aeg ja kultuuritarbimine. [Leisure time and consumering of the culture] In Töö, kodu ja vaba aeg. Argielu Eestis aastatel 1985-2008. Tallinn: Tallinna Ülikooli RASI, 171191.

Prout, A., James, A. (2005). A New Paradigm for the Sociology of Childhood? Provenance, promise and problems. In Childhood. Critical Concepts in Sociology. Edited by Chris Jenks. London and New York. Routledge. Vol 1, 56-80.

Reiman, H. (1930). Õpilaste edasijõudmine koolides. [Pupils' coping in school] Kasvatus, 4, 155-164.

Sarv, E. S. (2008). Õpetaja ja kool õpilase arengu toetajana. Opetaja enesest ja koolist. [Teacher and school supporting pupils' development. Teacher about her/himself and about school] Tallinn: Tallinna Ülikool.

School as Developmental Environment and Students' Coping: Aspects of Estonian school today (2008). Compiled and edited by Loone Ots. Tallinn: Tallinn University.

Skelton, C. (2001). Schooling the boys. Masculinities and primary education. Buckingham, Philadelphia: Open University Press.

Spielhofer, T., Benton, T., Evans, K., Featherstone, G., Golden, S., Nelson, J., Smith, P. (2009). Increasing Participation. Understanding Young People who do not participate in Education or Training at 16 and 17. National Foundation for Educational Research. Research Report DCSF-RR072. 
PROBLEMS

OF EDUCATION

IN THE $21^{\text {st }}$ CENTURY

Volume 48, 2012

126 Tamm, S. (1979). Koolistressi ilmingud ja õppeedukus. [Phenomena of school stress and student achievement] Nõukogude Kool, 4, 36-38.

Tulva, T. (1992). Tüdrukud ja poisid lasteaias. [Girls and boys in Kindergarten] Haridus, 6, 40-42.

Tulva, T., Tamm, S. (1971). Mõningaid algklasside õppeedukuse pedagoogilis-meditsiinilisi aspekte. [Some pedagogical-medical aspects of the student achievement in primary grades] Nõukogude Kool, 11, 829-833.

Tulva, T., Väljataga, S. (1999). Põhikool siirdeühiskonna kasvuraskuste taustal. [Basic school in the context of the problems of transitional society] Haridus, 2, 20-23.

Vinter, K. (2006). Õpetaja 6-7-aastaste tõrjutute ja liidrite sotsialiseerijana sooerinevustest lähtuvalt. [The teacher as a socialiser of peer-rejected and leading 6-7-year olds on the basis of gender difference] Magistritöö. Tallinna Ülikool.

Advised by Kristina Nugin, Tallinn University, Tallinn, Estonia

Received: September 25, 2012

Accepted: November 05, 2012
Mare Müürsepp

PhD, Associate Professor, Tallinn University, Institute of Educational Sciences, 25 Narva Rd Tallinn 10120, Estonia.

E-mail: mare.muursepp@tlu.ee

Website: http://www.tlu.ee
PhD, Associate Professor, Tallinn University, Institute of Educational Sciences, 25 Narva Rd Tallinn 10120, Estonia.

E-mail: anne.uusen@tlu.ee

Website: http://www.tlu.ee 